\title{
Professional Educational Offer And Its Impact On The Labour Market
}

Emma Rosa Cruz Sosa, Benemérita Universidad Autónoma De Puebla, Mexico

Patricia Eugenia García Castro, Benemérita Universidad Autónoma De Puebla, Mexico Laura Gática Barrientos, Benemérita Universidad Autónoma De Puebla, Mexico Jesús Hernández García, Benemérita Universidad Autónoma De Puebla, Mexico

\begin{abstract}
The fact that in México a large part of the population has access to higher education institutions, both public and private, does not indicate that the students are going to have the opportunity of developing the knowledge acquired in the university. Unemployment is often present; therefore their hopes to get a better life are diminished. Nowadays, students have a college degree, but they do not have any place to work. What is worse is that they cannot go back to their place of origin, because they are not accustomed to the former life or any other profession that they would have probably exercised if they had not lived in the city, causing underemployment. The higher education system in Puebla shows a high efficiency to cover the requirements of skilled labour of the economy, but it is not its duty to improve the performance of the economic and political institutions in order to reach an efficient and dynamic economy. It is worth mentioning that urgent actions are required to improve social conditions, as part of an integral strategy, which will allow the Mexican economy to increase the competitiveness of the companies, and thus achieve a greater job demand.
\end{abstract}

Keywords: Mexican Economy; Mexican Educational System

\section{INTRODUCTION}

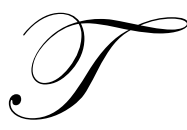

he labour market is the core of the national economic life. This is such a big market that many factors go beyond any labour policies can affect its performance. The educational, physical, monetary, commercial, and social development policies have important effects on the market. Achieving a more competitive market is essential for society to recover the investment made on human capital. A more competitive market will enable the growth of potential individual professionals, as well as the adoption and development of new technologies, which in the long term will provide a greater social welfare for everybody.

The stronger discussion about relationship between the graduates of the institutions of higher education (IHE) and the economic sector is about the occupations of the professionals. In fact, there have been documented different points of view regarding the professionals who do not carry out their jobs in accordance with their education they are considered as unemployed. These underemployed professionals represent an inefficient educational system. The problem is complex, according to the data obtained from the National Institute of Statistics, Geography and Computing (INEGI), only 50\% of the workers perform duties related to their career.

It is surprising that the percentage of university graduates searching for a job are hired into the informal market while they find a better job.

There are professionals who do not have any chance to enter the labor market, therefore they have to work for the informal market; situation provoked by the same labor discouragement. 
Muñoz (1992) argues that it is desirable to achieve a greater convergence between the flow of graduates and the requisites of the productive apparatus in order to reduce the deficit of human resources, which limits the economic growth and, at the same time reducing the underemployment and unemployment of the higher education graduates.

The decreasing economic resources will provoke a reduction of the "unwanted" educational offer, allowing the creation of private institutions of dubious quality in order to cover the offer that the public higher education institutions cannot provide.

The aim of this work is to determine whether the formation of capable professionals in different areas of science, technology, culture and teaching, graduated from higher education institutions in Puebla guarantees their insertion into the labor market with enough job offers for the total of graduates.

\section{LITERATURE REVIEW}

The world dynamics and the forces that propel the economical development of the nations are generating deep transformations in higher education. Words that are difficult to find in the vocabulary of the higher education, 20 years ago, such as: competitiveness, globalization, market forces, customers, industrial parks, industrial innovation, transnational education, and regional development are now being used frequently in university campuses and in the university development plans, as well as, in publications and magazines dedicated for higher education.

A big difference exists between expending and investing, the first generates immediate satisfaction or benefits, whereas the investments produce some kind of asset in the future. These assets are called Capital. Education can be seen as an investment, in a process where human capital is created. As well as the fixed asset: machinery and real estate generates cash flow for their owners in the long run; in the same way the education will help individuals to increase their incomes along their lifetime. In this sense, there is a clear relationship between fixed asset and human capital.

The theory of human capital lays the foundation for studying the relationship between education and economy. This relationship exists in the labour market, since it is clearly seen that the individuals increase their profits in accordance with their education level. Education and in particular higher education are important elements for the development of societies and to drive the economic growth. (Lustig, Arias y Rigolini 2002).

Thus, the countries with a higher level of development show better results in their educational performance, measured by the quality or coverage of their services. The paper "Education at a Glance 2006", published by the Organization for Economic Cooperation and Development(OECD), describes how investing in education and especially in higher education generates high social and private yields. Highly prepared people are essential for the generation of new knowledge, for development of businesses and for the having the ability of finding solutions to new and old problems that face society. Generations of graduates and their employment are very important not only for themselves, but also for the economic advancement of countries. In fact, the OECD suggests that countries should increase the percentage of college graduates in their total population.

In the last quarter of the 20th century, Latin America has experienced a huge increase of students enrolling to higher education institutions. Currently, there are more than 12 million students enrolled, half of them are in Mexico, Brazil and Argentina. Despite the assistance rate of advanced education, in these three countries, it represents only $20 \%$ of young people in corresponding ages to that level of education.

In the 1990s, neo-liberal strategies were introduced in the context of globalization, which tended to substitute state welfare policies by others where the market conceptions and privatization of public services, such as education, were predominate. The national economic crises led to a strong limitation to finance the public and social sectors particularly in education. In the 90 s, the population increased its demand for advanced education, as a result of globalization. Fernández affirms that the number of students of higher education increased more than thirty times, between 1950 and 2000. 
These figures are shown in Table 1:

Table1. Number Of Higher Education Students In Latin America.

\begin{tabular}{|c|c|}
\hline Year & Number Of Students \\
\hline 1950 & $267.000(2 \%)$ \\
\hline 1970 & $1.640 .000(6.3 \%)$ \\
\hline 1980 & $4.930 .000(13.8 \%)$ \\
\hline 1990 & $7.353 .000(17.1 \%)$ \\
\hline 2000 & $12.000 .000(19 \%)$ \\
\hline
\end{tabular}

The gross rate of advanced education increased almost ten times in the second half of the 20th century. Despite this important growth, the rate is still very low compared with rate of developed countries, which was $51.6 \%$ in 1997. Nevertheless, the increase of public advanced education enrollment in Latin America and in the private educational sector generated a strong diversification of higher education, as well as a great heterogeneity of quality levels. In this way, a large number of private universities are created, which are termed 'garage universities', due to their dimension, low quality and type of available physical infrastructure. In fact, the International Institute for Higher Education in Latin America and the Caribbean of the UNESCO, has not been able to have precise regional information about the number of existing institutions of this level, so far.

In the publication "Employment Perspectives 2007" of the OECD, shows a great inequality of economic growth, an increase of the informal employment and the lack of social coverage, among other topics. It was argued that globalization is associated with economic growth. Therefore it must be recognized that because of globalization there is a growth in the inequality of wages among workers and it is easy to lose your job, etc.

Nowadays, companies are beginning to work in new areas and niches, and people tend to move into new lines of work, that is why, the OECD proposes a global policy framework coherent to improve the safety of workers and to mobilize the unemployed. It was concluded that this might promote a person to return to work quicker. Nonetheless the organization makes clear that the unemployed might feel pressured to accept jobs for which they are not competent. Furthermore we must not forget that jobs must have good labour conditions in order to make them more stable.

A more competitive market will enable the advance of the individual potential of professionals, as well as the adoption and development of new technologies, which in the long term will provide a greater social welfare for everybody.

The labor market is the core of the national economic life. This is such a big market that many factors that go beyond any labor policy can affect its performance. The educational, fiscal, monetary, commercial, and social development policies have important effects on it. Achieving a more competitive market is essential for the society to recover the investment made on human capital.

Muñoz (1992) argues that it is desirable to achieve a greater convergence between the flow of graduates and the requisites of the productive apparatus in order to reduce the deficit of human resources, which limits the economic growth and, at the same time reducing the underemployment and unemployment of the higher education graduates.

This author points out several causes for these two problems, among which the performance of the economy is one of them. Muñoz also argues that the registration should be redirected to careers related to the development of technology and the reduction of the number of students enrolled in administration careers. In spite of recognizing that the economic structure is an important factor in the composition of enrollment in higher education, this author states that the solution to the problem is in the higher education. Muñoz suggests: 1) that higher education institutions can influence students in choosing professions, 2) that higher education institutions can offer cheaper courses in terms of material and human resources, 3) and that primary and secondary schools promote learning science. 
According to Partida V., in past decades, México has experienced a period of economic growth and stable employment, however has also suffered economic crises. Subsequently, with the transformations of economies, the processes of integration, the restructurings and the downturns in international economies, the economic, political and social conditions of the country intensified. On one hand, it was stated that the globalization would open new opportunities for economic growth and create more jobs, but in fact, the opposite happened. The economic structure and the status of work were affected.

In the same way, the neo-liberal development model adopted by Mexico, focuses on exterior economical activity, provoking problems in holding a sustained growth, compatible with job creation.

The transformations and changes in the economy happened in a highly heterogeneous labour market. As a result, companies linked to modern markets have coexisted nationally and internationally with a growth in the informal market. This is constituted by a variety of businesses which present different forms of work, characterized by deregulation and the increase of labour precariousness.

There are many studies and critical views about the higher education system. For decades it has been noted that there are too many types of college graduates which have no future. Therefore some reductions and regulations have been proposed in order to control the career options of higher education.

In a recent statement a summary of these positions were given by the Secretary of Higher Education, Rodolfo Tuiran Gutierrez, "Unfortunately, in this country, we continue to produce an abundance of professionals of a certain type and we are not producing other groups of professionals. Particularly in the case of labour markets, the country has around 5.3 million professionals and one out of every three are either accountants, managers or lawyers."

The stronger discussion about relationship between the graduates of the institutions of higher education (IHE) and the economic sector is about the occupations of the professionals. In fact, there have been documented different points of view regarding the professionals who do not carry out their jobs in accordance with their education, they are considered as unemployed. These underemployed professionals represent an inefficient educational system. The problem is complex, according to the data obtained from the National Institute of Statistics, Geography and Computing (INEGI), only $50 \%$ of the workers perform duties related to their career.

It is the duty of the educational system that students and workers learn how to use the technology. As well as raising the quality, coverage and terminal efficiency of the education. But definitively, the educational system is not the duty to get better the performance of the economic and political institutions in order to achieve a more efficient and dynamic economy.

\section{METHODOLOGY}

This is not experimental research; different sources were used to carry out the literature review, such as books, newspaper library, internet and statistics obtained from the federal and state government of Puebla. Fieldwork and documentary research were carried out, including information obtained from books, internet, newspaper library and statistics of the federal government and government of state of Puebla.

In order to carry out fieldwork, several questionnaires were applied to 383 graduated from different institutions of higher education of state of Puebla.

\section{DELIMITATION}

- The research is about the Institutions of Higher Education and the labour market of the State of Puebla.

- $\quad$ The surveys were applied in May, 2009.

- The present research is based on the information obtained from the total of the companies, Institutions of Higher Education and their graduates in the State of Puebla, this is not a comparative work. 


\section{LIMITATION}

The census of population 2005 was taken into account in the present research, but the census of population 2010 was not, since it had not been taken when this work was carried out.

\section{CONTEXT OF PUEBLA}

\section{Location}

Puebla is one of the 31 states of the Mexican republic its capital city has the same name. Its area is approximately $34,251 \mathrm{~km}^{2}$. The capital of the state is 129 kilometers east from Mexico City, and it can be reached by land or air. The state of Puebla borders Veracruz to the east and north, State of Mexico, Hidalgo, Tlaxcala and Morelos to the west, Oaxaca and Guerrero to the south. Puebla has no outlet to the sea and it presents an extremely rugged relief. Puebla has several highways and roads which link to the rest of the country.

\section{Economy}

The economic sector of Puebla is represented by the manufacturing industry, which especially produces textile products. This sector is situated in the central regions of the state and the Tehuacan Valley. However, 60 percent of the economy of the state is based on the different trade areas, as well as the performance of diverse services.

Also there are many people with an economy based on agriculture, but due to the adverse conditions facing this sector in Mexico, many of them have been dismantled and they have become a source of unskilled labor, provoking migration. In fact, some people of those communities rely mainly on remittances sent by members of these communities living and working abroad.

As for the economic growth of state of Puebla, the governor Mario Marín Torres expressed in his development plan (2005), the following: "In the absence of significant changes, the growth of the Mexican economy will average about $3.5 \%$ per annum, implying an increase per capita of about $2.4 \%$. In case of maintaining this situation, it would take 30 years to increase the double of the level of per capita income."

In 2007, the gross domestic product of Puebla presented the following figures: $26 \%$ corresponding to the manufacturing industry; in second place $18.8 \%$ corresponding to restaurants and hotels; the sector of the construction shows $3.6 \%$ and banking services with $1.8 \%$. This data shows that the activities mentioned above are the main activities in the state. On the other hand, the least exploited activities are mining, electricity, gas, water and construction.

Regarding the number of companies established in the state, it is shown a considerable decrease, since in 2001, there were 15952 businesses, whereas in 2008, there were only 10555. As shown in Table2:

Table 2: Companies In Puebla State

\begin{tabular}{lcccccccc}
\hline State & \multicolumn{8}{c}{ Companies Into The System } \\
& 2001 & 2002 & 2003 & 2004 & 2005 & 2006 & 2007 & 2008 \\
Puebla & $\mathbf{1 5 , 9 5 2}$ & $\mathbf{1 4 , 5 7 7}$ & $\mathbf{1 5 , 5 7 7}$ & $\mathbf{1 4 , 6 6 8}$ & $\mathbf{1 3 , 4 3 4}$ & $\mathbf{1 0 , 6 1 1}$ & $\mathbf{1 0 , 6 8 9}$ & $\mathbf{1 0 , 5 5 5}$ \\
\hline
\end{tabular}

http://www.siem.gob.mx/siem2008/portal/estadisticas/Est_Amb_xMun.asp?qedo=21

\section{Population}

Puebla has a population of 5,383,133 inhabitants; it means that Puebla is the fifth more populated state of the country. In the region known as "Sierra Norte" of Puebla, which is part of the Sierra Madre Oriental, the largest part of the population of indigenous people speak Nahuatl. 


\section{Population growth}

The censuses have been taken from 1900 to 2000, and the second census of population and Housing 2005 shows the population growth of the state of Puebla. As shown in the figure 1: from 1900 to 2005, the number of people in Puebla increased five times, whereas from 1970 to 1990, Puebla suffered a population explosion. A high number of people moved to live to Puebla city after the earthquake suffered in the Mexican capital, on the $19^{\text {th }}$ of September of 1985 .

Graphic 1: Total Population Of The State Of Puebla (1900 - 2005).

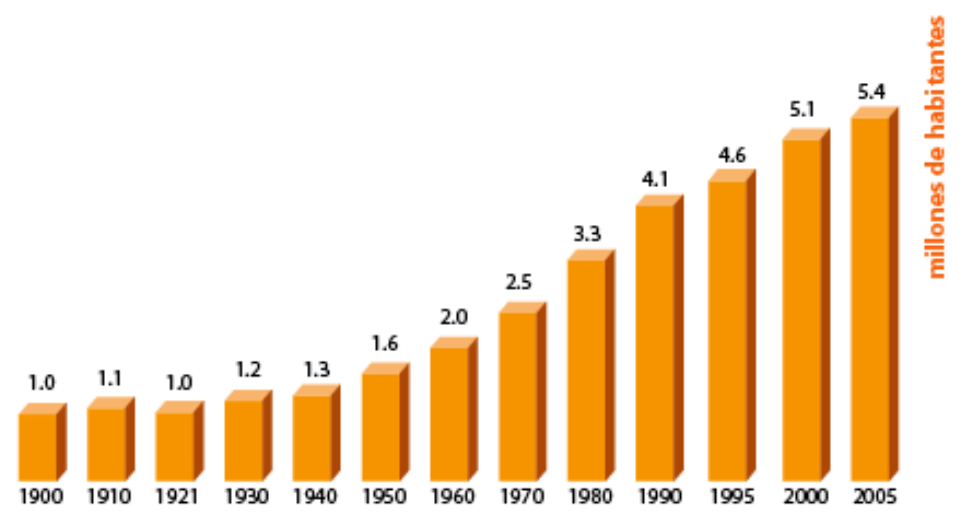

Source: INEGI. Socio-demographic profile. Second census of population and housing 2005

INEGI. Socio-demographic profile. First census of population and housing 1995

\section{Institutions Of Higher Education In Puebla}

In México, the higher education is imparted by a large number of institutions. All of them grant the university degree. Public institutions receive funds from government for their operation, allowing them to offer free education or at very low costs for their students. Private schools have own resources obtained from registration, tuition fees and different services (Rubio;1995).

In the last 30 years, the higher education institutions in Puebla have considerably increased. If we take into account that in the 70's the only institutions of higher education that existed in the state were: the Benemérita Universidad Autónoma de Puebla (BUAP) dating from 1578, obtaining its autonomy in 1956, which is the only public university. The second one was the Universidad de las Americas (UDLA), founded in 1967; subsequently the Universidad Popular Autónoma del Estado de Puebla (UPAEP), dating in 1973. Both universities are private.

Afterwards, five new prívate universities were created, such as: Universidad Cuauhtémoc, Universidad del Valle, Universidad Iberoamericana, Instituto Tecnológico de Puebla y Universidad Realística de México.

It is relevant to make clear that the Benemérita Universidad Autónoma de Puebla has been a regional university, which has accommodated students not only from Puebla but also from other states such as Tlaxcala, Morelos, Veracruz, Tabasco, Oaxaca, Chiapas and Guerrero, among others. In order to satisfy the needs of the students as well as raising the quality of education, in the 90's, the university started applying a rigorous entrance examination. The College Board is in charge of it with this test a large number of applicants are rejected. For instance, in 2009, there were 40,000 applicants, being accepted only 15,000. That is why new universities were created in the entity, mostly private, in which the demanding student population gathers. It provoked a huge increase of higher education within the state, counting so far with 238 schools. 


\section{Graduates from the institutions of higher education}

In order to facilitate access to higher education, some of these institutions have established new campuses in the largest cities of the state. In 2005 existed 200 institutions; while in 2008 it was possible to count 238. This represents an increase of $19 \%$ in three years. In fact, the state government has published it in its website: http://www.puebla.gob.mx. In the same way, on the $13^{\text {th }}$ of August of 2008 , the Universal Daily published the following:

Puebla city is one of the most important metropolis in México, in fact, it is the fifth one as to the number of inhabitants. Also Puebla has too many students due to the large number of universities and professors in the state.

Likewise Puebla is second city in México regarding the number of universities both public and private.

The university Graduates from the institutions of higher education, in the state of Puebla rose to 136,672 in 2007. As shown in the Table 3:

Table 3:Graduates From Bachelor'S Degree

(In Thousands)

\begin{tabular}{|c|c|c|c|c|}
\hline \multicolumn{5}{|c|}{ Bachelor'S Degree } \\
\hline State & Technician & $\begin{array}{c}\text { College } \\
\text { And Technological }\end{array}$ & $\begin{array}{c}\text { Teacher's Training } \\
\text { College }\end{array}$ & Total \\
\hline Aguascalientes & 2,224 & 24,131 & 3,168 & 29,523 \\
\hline Baja California & 1,196 & 57,941 & 2,851 & 61,988 \\
\hline Baja California Sur & & 12,451 & 1,020 & 13,471 \\
\hline Campeche & 1,567 & 15,864 & 2,239 & 19,670 \\
\hline Coahuila & 4,171 & 55,540 & 5,117 & 64,828 \\
\hline Colima & 432 & 13,959 & 706 & 15,097 \\
\hline Chiapas & 1,748 & 52,213 & 3,770 & 57,731 \\
\hline Chihuahua & 2,950 & 68,886 & 4,441 & 76,277 \\
\hline Distrito Federal & 1,171 & 356,505 & 8,445 & 366,121 \\
\hline Durango & & 25,534 & 4,686 & 30,220 \\
\hline Guanajuato & 5,172 & 61,741 & 6,276 & 73,189 \\
\hline Guerrero & 1,635 & 38,913 & 8,836 & 49,384 \\
\hline Hidalgo & 4,047 & 42,619 & 3,403 & 50,069 \\
\hline Jalisco & 5,535 & 142,569 & 6,860 & 154,964 \\
\hline Estado De México & 8,386 & 227,446 & 7,673 & 243,505 \\
\hline Michoacán & 454 & 65,919 & 5,541 & 71,914 \\
\hline Morelos & 1,296 & 30,737 & 3,374 & 35,407 \\
\hline Nayarit & 2,208 & 17,964 & 3,254 & 23,426 \\
\hline Nuevo León & 2,687 & 119,784 & 7,111 & 129,582 \\
\hline Oaxaca & & 47,976 & 7,334 & 55,310 \\
\hline Puebla & 8,187 & 116,745 & 11,740 & 136,672 \\
\hline Querétaro & 3,902 & 30,143 & 2,123 & 36,168 \\
\hline Quintana Roo & 1,822 & 14,615 & 666 & 17,103 \\
\hline San Luis Potosí & 1,282 & 43,619 & 2,966 & 47,867 \\
\hline Sinaloa & 880 & 74,129 & 1,316 & 76,325 \\
\hline Sonora & 4,278 & 64,762 & 1,834 & 70,874 \\
\hline Tabasco & 2,995 & 51,852 & 1,667 & 56,514 \\
\hline Tamaulipas & 3,685 & 77,103 & 6,344 & 87,132 \\
\hline Tlaxcala & 564 & 18,238 & 2,536 & 21,338 \\
\hline Veracruz & 1,766 & 116,915 & 4,937 & 123,618 \\
\hline Yucatán & 2,929 & 40,285 & 2,284 & 45,498 \\
\hline Zacatecas & 1,007 & 23,048 & 1,821 & 25,876 \\
\hline
\end{tabular}

Source: http://www.anuies.mx/servicios/e educacion/index2.php, 2007 


\section{Economically Active Population Of The State}

The presidential period of Felipe Calderon began with an official unemployment rate of $3.58 \%$ of the working population, almost 1.575 million of unemployed Mexicans. This underemployment affects about 2.9 million people (6.5\% of the working population). Nine months later, the unemployment rate rose to $3.92 \%$ of the working people and the underemployment rate came to $6.6 \%$, without taking into account that 380,000 people emigrated to the United States.

Regarding the State of Puebla, the Table 4 shows figures about working population. The most recent information corresponds to the first trimester of 2006.

Table 4: Economically Active Population Of The State (Eaps)

\begin{tabular}{|l|c|c|c|}
\hline & Total & Men & Women \\
\hline Economically Active Population Of The State (EAPS) & $2,325,623$ & $1,412,783$ & 912,840 \\
\hline
\end{tabular}

INEGI. Second census of working population corresponding to the first semester of 2005.

\section{Unemployment and Underemployment}

Although most of the institutions of higher education fulfill the established quality standards, the universities cannot be in charge of finding jobs for all their graduates. The number of possibilities depends on the general economic situation of the country, as well as the own needs of the companies. Therefore the labor positions result to be insufficient to accommodate so many graduates, provoking underemployment or total unemployment.

Table 5

Table 5: Unemployed And Underemployed Population In The State Of Puebla.

\begin{tabular}{|l|c|c|}
\hline & Total & Men \\
\hline Unemployment And Underemployment & 454,669 & 140,731 \\
\hline
\end{tabular}

INEGI. Second census of working population corresponding to the first semester of 2005

\section{Determination of the size sample}

The formula used to obtain the sample is indicated by Lourdes Munich 2000:

$n=\frac{Z^{2} p q N}{N e^{2}+Z^{2} p q}$

Where:

$\mathrm{n}=$ Sample size

$\mathrm{Z}=$ Safety margin $95 \%=1.96$

$\mathrm{p}=$ Probability of positive response $=0.50$

$\mathrm{q}=$ Probability of negative response $=0.50$

$\mathrm{N}=$ Population $=136,672$ students

$\mathrm{e}=$ Margin of error $=5 \%$

Substituting the values, we have:

$$
\begin{aligned}
& n=\frac{(1.96)^{2}(0.50)(0.50)(136,672)}{(136,672)(0.05)^{2}+(1.96)^{2}(0.50)(0.50)} \\
& n=\frac{(3.8416)(0.50)(0.50)(136672)}{(136,67)(0.0025)+(3.8416)(0.50)(0.50)}
\end{aligned}
$$




$$
\begin{aligned}
& n=\frac{131,259.78}{341.68+0.9604} \\
& n=\frac{131,259.78}{342.64} \\
& \mathbf{n}=383
\end{aligned}
$$

By using the formula, it was established that representative sample is equal to 383 students

\section{ANALYSIS AND INTERPRETATION OF RESULTS OF THE SURVEY}

For practical reasons, we are just going to show the interpretations of the questions asked the respondents.

\section{Mention The Name Of The University From Which You Graduated}

According to the answers expressed by students, $73 \%$ are graduates from some of the different careers offered by Benemérita Universidad Autónoma de Puebla, whereas $27 \%$ come from other institutions, such as: the Universidad Popular Autónoma del Estado de Puebla, Universidad Iberoamericana, Instituto Tecnológico de Puebla, Universidad Autónoma de Tlaxcala, among others.

\section{Did You Know That There Are More Than 238 Higher Education Institutions In The State Of} Puebla?

Twenty nine percent of the surveyed students were unaware of the existence of large number of Institutes of Higher Education in the state, whereas the remaining $71 \%$ said that they knew of such figures.

\section{Is The Labour Market Sufficient To Employ The Total Number Of Graduates From Different Institutions Of Higher Education In The State?}

The majority of respondents knew that the labor market is insufficient in order to accommodate the total of graduates from the institutions of higher education.

\section{The Creation Of Higher Education Institutions Is The Result Of:}

In this question, the majority of respondents agree that the higher education institutions of the state of Puebla have been created as businesses; in 2nd place, the surveyed students answered that the government tends to privatize the higher education. A smaller part of respondents thinks that it is due to the saturation of some degrees and because the institutions of higher education are necessary.

\section{Are There Sufficient Labour Sources, According To Career You Chose ?}

In this question, most people said that there are not enough jobs according to the career that the students chose and a smaller percentage thinks that the sources of income are sufficient for all graduates from institutions of higher education.

\section{Is Your Salary Enough To Satisfy Your Needs ?}

According to the results of this question, the majority of respondents answered that their wage does not satisfy all their needs so that it just serves to cover basic needs, therefore they have to work in a different activity in order to cover them. Only $16 \%$ of respondents considered that their salary is sufficient to cover their needs. 


\section{Taking Into Account Our Current Economy, The 238 Institutions Of Higher Education Have:}

The majority of respondents consider that there is a great demand for jobs and a low job offer, which is a consequence of the huge numbers of higher education institutions.

\section{According To Your Point Of View, What Is Happening To The Graduates Of Your Degree ?}

As a result of the huge numbers of higher education institutions in the state, the respondents consider that the undergraduate students suffer, in 1st place, low wages; secondly unemployment; in third place, they recognized the need to take specialization courses in different disciplines in order to face the labor competencies on graduating from the higher education institutions; and finally they suffer underemployment.

\section{What Kind Of Labor Problems Do Your Schoolmates Suffer ?}

Respondents estimated that $31 \%$ of their schoolmates are unemployed, $46 \%$ work in different activities from their career and only $23 \%$ practice their profession.

\section{Before The Global Economic Crisis, Was It Easy To Obtain Employment, High Salaries By Applying} The Knowledge Acquired?.

A significant percentage of respondents expressed that before the global economic crisis, it was already difficult to find a job in order to practice their profession and what is more difficult, with high wages.

From the present research, it is concluded the following results:

In 2007 the economy of the State of Puebla was composed of 10,689 companies and 238 institutions of higher education from which 136,672 students graduated each year. Dividing the number of companies by the number of graduates, results a visible deficit of jobs, which means that the companies cannot hire all graduates.

Some existing high schools began to offer studies of higher education, joining the existing higher education institutions and therefore joining the Secretary of Public Education (SEP), which has increased the number of higher education institutions in the state.

It is noteworthy that the majority of Higher Education Institutions offer degree courses, such as Business Administration, Accounting, Law, Economics, etc., provoking saturation in those careers.

It is important to mention that the labor market has not been able to grow, due to the lack of opportunities from the government, such as: 1.) tax exemptions, 2.) granting of lands, 3.) construction of industrial parks to set up businesses, etc.

Therefore they have to study a postgraduate enabling them to have better training in order to compete in the labor market and thereby improve their level of incomes. In concrete, there have always been unemployment and underemployment, including before the world economic crisis.

\section{CONCLUSION}

The fact that in México, a large part of the population has access to higher education institutions, both public and private, it does not indicate that the students are going to have the opportunity of developing the knowledge acquired in the university. Unemployment is often present; therefore their hopes to get a better life are diminished. Nowadays, students have a college degree, but they do not have any place to work. What is worse is that they cannot go back to their place of origin, because they are not accustomed to the former life or any other profession that they would have probably exercised if they had not lived in the city, causing underemployment. 
It is urgent to take actions to improve the social conditions, as part of an integral strategy, which allows the Mexican economy to increases the competitiveness of the companies and thus achieve a greater creation of jobs.

\section{PROPOSITIONS}

Propositions to achieve a balance between graduates from higher education institutions and the labor field:

1. Both the Federal Government and the State must undertake the commitment to establish regulations in order to create higher education institutions with the aim of controlling the saturated careers.

2. The Government must develop studies to determine the number of professionals required by the labor market.

3. The higher education institutions must develop strategies to face the challenge of diversifying the professions not only for higher education, but to create new technical careers and trades.

4. It is important to promote the vocational guidance, since its results will impact on the future professionals and society in general, leaving aside the fashion careers.

5. Do not keep establishing higher education institutions without an appropriate planning, since the results show a large number of graduates without a job or a job with a low wage.

6. It is necessary to design an integral strategy, which considers different aspects of higher education without stopping taking into account the requisites of the labor market in order to balance the number of professionals regarding the number of jobs.

7. Implementing and promoting enterprising programs in all the higher education institutions, so that the graduates from these institutions can independently practice their profession, ensuring their own incomes in order to raise their standards of living, as well as creating sources of employment.

\section{AUTHOR INFORMATION}

Emma Rosa Cruz Sosa, Profesora Investigadora de la Unidad de Planeación, Investigación y Evaluación, así como miembro del Centro de Investigación, de la Facultad de Contaduría Pública. Benemérita Universidad Autónoma de Puebla. México. Email: emmarc2001@yahoo.com.mx

Laura Gatica Barrientos, Profesora Investigadora de la Unidad de Planeación, Investigación y Evaluación, así como miembro del Centro de Investigación, de la Facultad de Contaduría Pública. Benemérita Universidad Autónoma de Puebla. México. Email: ekalg@ hotmail.com

Patricia Eugenia Garcia Castro, Profesora Investigadora de la Unidad de Planeación, Investigación y Evaluación, así como miembro del Centro de Investigación, de la Facultad de Contaduría Pública. Benemérita Universidad Autónoma de Puebla. México. Email: patricia.garcia@fconta.buap.mx

Jesús Hernández García, Profesor Investigador de la Unidad de Planeación, Investigación y Evaluación, así como miembro del Centro de Investigación y del departamento de Inglés de la Facultad de Contaduría Pública de la Benemérita Universidad Autónoma de Puebla. México. Email: master7@live.com.mx

\section{REFERENCES}

1. $\quad$ ANUIES. Anuarios Estadísticos, México, ANUIES, 1980-2004.

2. Becker, G. S. Human Capital: A Theoretical and Empirical Analysis, with Special Reference to Education, Princeton, Princeton University Press, 1975.

3. Economics of Education. Research and Studied, Nueva York, Pergamon Press, 1987.

4. Shultz, T. W. "Investment in Human Capital", en American Economic Review, 51, 1961, pp. 1-17.

5. Freeman, R. Implications of the changing US. labor market for higher education, NBER Working Paper núm. 697, 1981.

6. Hernández Laos (coord.). Mercado laboral de profesionistas en México. Diagnóstico y prospectiva al año 2010, México, CIESA, 2002.

7. INEGI. Sistema de Cuentas Nacionales de México, México, INEGI. 
8. Katz, I. M. “Apertura comercial, cambio tecnológico y educación”, en I. J. Beristain. México al filo del año 2000, México, ITAM, 1989.

9. Lustig, Arias y Rigolini. Reducción de la pobreza y crecimiento económico. La doble causalidad, Serie de informes técnicos del Departamento de Desarrollo Sostenible (POV-111) BID, 2002

10. Mincer, J. Schooling, experience and earnings, Nueva York, NBER, 1974.

11. Muñoz, C. "Relación entre la educación superior y el sistema productivo", en G. Arredondo. La educación superior y su relación con el sector productivo, México, ANUIES, 1992.

12. OECD. Education at a Glance, París, $O E C D, 2006,465$ pp.

13. Ontiveros, M. y L. Meza. Salarios profesionales. Una guía para la elección de carrera,

14. Psacharopoulos, G. "Returns to education: An updated international comparison", en Com. Educ. 17, 1981, pp. 321-341.

15. Tanvir Jertalum, 2001. Pliego, A. "Educación superior y mercado laboral en México", Tesis de licenciatura, ITAM, 2001.

16. 268 Revista Latinoamericana... Vol. XXXVII, NÚMS. 3-4, 2007

17. "Education and Population Quality", en G. Psacharopoulos (ed.). Economics of Education. Research and Studies, Nueva York, Pergamon Press, 1987.

18. Strumlin, S. G. The economic significance of national education, París, UNESCO, 1968.

19. UNESCO. Readings in the Economics of Education: A Selection of Articles, Essays and Texts from the Works of Economists,

20. Past and Present, on the Relationships between Economic sand Education, Paris, UNESCO, 1968

21. Ariza, M. y Orlandina de Oliveira (2001). "Familias en transición y marcos conceptuales en redefinición". En: Papeles de Población, abril/junio, Núm. 28. UAEM. pp. 9-39.

22. Ariza, M. y Juan Manuel Ramírez (2005). "Urbanización,

23. mercados de trabajo y escenarios sociales en el México finisecular". En: A. Portes, B. R. Roberts, y A. Grimson (eds.). Las ciudades latinoamericanas a comienzos del siglo, Buenos Aires: Prometeo Editores.

24. Balderas, A. (1997). Las trabajadoras y el patrónneoliberal en México. En: Papeles de Población, octubre/diciembre, Núm. 18. UAEM. pp. 145-170.

25. Castillo, V; Sofía, Rojo y Gabriel Yoguel (2005).

26. "Trayectorias laborales y rotación del empleo

27. 1996-2004”. En: Trabajo, ocupación y empleo. Trayectorias, negociación colectiva e ingresos. Serie Estudios Núm. 2, Ministerio de Trabajo y Seguridad Social, Buenos Aires.

28. Chacaltana, J. (2000). Red de Políticas de Empleo,

29. Chitarroni, H. (2003). Cambios en los flujos laborales

30. (1998-1999/2001-2002). Instituto de Investigación en Ciencias Sociales (IDICSO), Buenos Aires.

31. Chitarroni, H. (2001). "Las trayectorias de desempleo".

32. En: Revista Laboratorio Núm. 8, año 4. Informe de coyuntura laboral del programa de cambio estructural y desigualdad social del IIGG, FCSUBA Buenos Aires.

33. Consorcio de Investigación Económica y Social. [en línea: http://cies.org.pe/es/node/173]

34. Diez de Medina, R. (2001). Jóvenes y Empleo en

35. los Noventa en América Latina. CINTERFOR-OIT, abajo: Examen de sus objetivos, métodos de recogida y problemas de medición". En: Ralph Turvey (Comp.). Avances recientes en las estadísticas internacionales del trabajo. Colección informes OIT, Núm. 39. Ministerio del Trabajo y Seguridad Social. Madrid, España.

36. Rendón, T. y Carlos Salas (1993). "El empleo en México en los ochenta: Tendencias y cambios". En: Comercio Exterior Vol. 43 Núm. 8. Agosto de 1993. pp. 717-730.

37. OCDE (2007). Perspectivas del empleo.

38. OCDE (2006). Políticas públicas para un mejor desempeño económico. Experiencias del mundo para el desarrollo, México 10 años en la OCDE.

39. OIT $\left(2006^{\mathrm{a}}\right)$. Revista de la OIT, Trabajo Núm. 56, enero de 2006.

40. OIT (2006b). Panorama laboral, 2006.

41. OIT (2005). Qué es y qué hace la OIT [en Línea] www.ilo.org

42. OIT (2003). Key indicators of the labour market. $3^{a}$ edición. (Disco Compacto). Ginebra, Suiza

43. OIT (2002). Key indicators of the labour market. [En línea]. Disponible: www.ilo.org [2002, noviembre $10]$. 
44. OIT (1993). Resolución sobre las estadísticas del empleo en el sector informal, adoptada por la XV CIET. Ginebra, Suiza.

45. ONU (1998). Informe del Grupo de París sobre trabajo y remuneración. Segunda reunión. Comisión de Estadística.

46. Naciones Unidas. [En línea]. Disponible en http://www.insee.fr/en/nom_def_met/colloques/citygroup/ pdf/rapsce.pdf [2003, marzo 26].

47. OIT (1999). Informe del Grupo de París sobre trabajo y remuneración. Tercera reunión. Comisión de Estadística. Naciones Unidas. [En línea]. Disponible en pdf/rapsce.pdf [2003, marzo 26].

48. OIT (2000). Informe del Grupo de París sobre trabajo y remuneración. Cuarta reunión. Comisión de Estadística. Naciones Unidas. [En línea]. Disponible en: http://www.insee.fr/en/nom_def_met/colloques/citygroup/2000_meeting.htm [2003, marzo 26]

49. Partida, V. (2000). "Cambios en el mercado laboral urbano medidos con la esperanza de vida activa", ponencia presentada a la VI Reunión Nacional de Investigación Demográfica en México, agosto de 2000, México.

50. Pérez, J. y Maritza Urteaga (2001). "Los nuevos guerreros del mercado. Trayectorias laborales de jóvenes buscadores de empleo”. En: Pieck, E. Los jóvenes y el trabajo. La educación frente a la exclusión social. México UIA, IMJ, UNICEF, Cinterfor-OIT, RET, Conalep. pp. 333-354.

51. Portes, A. y William Haller (2006). "La economía informal”. En: Serie Políticas Sociales Núm. 100;CEPAL, noviembre de 2006.

52. Schumpeter, J. (1963). Capitalismo, Socialismo y Democracia. México FCE, 1963.

53. Schmitt, J. (2002). "Labor market transitions and the measurement of labor market capacity" paper prepared for meeting of the project on "New cross- National Architecture for Labor market Statistics" Bellagio, Italy.

54. Stibbard, P. (1999). "Labour market dynamics: A global survey of statistical activity”. Employment and training. Papers 38. OIT. [En línea]. Disponible http://www.ilo. org/english/employment/etp38.html [2002, junio 24].

55. Vuille, A. (1998). Dynamic analysis of the labour market Switzerland. Swiss Federal Statistical Office (SFSO). Londres, Inglaterra.

56. Weller, J. (2000). Reformas económicas, crecimiento y empleo: los mercados de trabajo en América Latina y el Caribe. CEPAL, Chile.

57. Weller, J. (1998). "La evolución del empleo en América Latina en los años noventa". En: Papeles de Población, octubre/diciembre, Núm. 18. UAEM. pp. 9-47.

58. www.matemáticas.com

59. http://www.enjoymexico.net/mexico/puebla-como-llegar-mexico.php

60. http://www.siem.gob.mx/siem2008/portal/estadisticas/Est_Amb_xMun.asp?qedo=21

61. http://www.ses4.sep.gob.mx

62. INEGI. Perfil Sociodemográfico. II Conteo de Población y Vivienda 2005

63. INEGI. I Conteo de Población y Vivienda, 1995.

64. Julio Rubio Oca (Coordinador 2006) 1995-2006. http://www.ses4.sep.gob.mx

65. http://www.anuies.mx/servicios/e educacion/index2.php

66. INEGI. Perfil Sociodemográfico. II Conteo de población económicamente activa trimestre enero a marzo de 2006

67. INEGI. Perfil Sociodemográfico. II Conteo de población desocupada y subempleada.

68. Secretaría Del Gobierno Del Estado De Puebla. http://www.puebla.gob.mx

69. Universia. http://www.universia.net.mx 


\section{NOTES}

